\title{
REVITALISASI KRAME BANJAR DALAM MENANGKAL WACANA RADIKALISME DI LOMBOK BARAT
}

\author{
Nazar Naamy \\ Fakultas Dakwah dan IImu Komunikasi UIN Mataram \\ e-mail: nazarpascamataram@gmail.com
}

\begin{abstract}
The Krame Banjar has lost its place since independence in 1945 until the reform of 1998. The change of authority model that started from the charismatic authority (master teacher), traditional (traditional leader) to the rational-legal authority (government) made the banjar kamame metamorphose into village meetings (MUSDUS), village deliberation (MUSDES) led directly to the ruling village (legal-formal). The generations of Krame Banjar have been replaced by the formal legal generation which in fact, when deliberate it is not uncommon to expect the village budget (ADD) to move, unlike the banjar Krame based on kinship among banjars. Krame Banjar in West Lombok became an arena in revitalizing the discourse of radicalism that developments both locally and nationally. This paper will explain Krame Banjar as the early information system for the successor to ward off the current discourse of radicalism.
\end{abstract}

\section{Key words:}

Discourse, Banjar Krame, Radicalism 


\section{Abstrak}

Krame Banjar ini kehilangan tempat dimulai sejak kemerdekaan tahun 1945 hingga reformasi tahun 1998. Perubahan model otoritas yang dimulai dari otoritas karismatik (tuan guru), tradisional (tokoh adat) menuju otoritas legal rasional (pemerintah) membuat Krame Banjar bermetamorfosa menjadi musyawarah dusun (MUSDUS), musyawarah desa (MUSDES) yang dipimpin langsung oleh kepada desa yang berkuasa (legal-formal). Generasigenerasi Krame Banjar telah tergantikan oleh generasi legal formal yang notabene ketika bermusyawarah tidak jarang mengharapkan anggaran dana desa (ADD) untuk bergerak, berbeda dengan Krame Banjar yang berbasis kekeluargaan antar banjar. Krame Banjar di Lombok Barat menjadi arena dalam merevitalisasi wacana radikalisme yang berkembang baik lokal maupun nasional. Paper ini akan menjelaskan lebih lanjut tentang Krame Banjar sebagai the early information system dari radikalisme.

\section{Kata Kunci:}

Wacana, Krame Banjar, Radikalisme 


\section{A. Pendahuluan}

Dalam beberapa dekade terakhir, selain demokrasi dan Hak Asasi Manusia (HAM), wacana yang muncul kepermukaan dalam khasanah politik domestik maupun internasional, khususnya yang berkaitan dengan persoalan agama versus negara adalah mengenai "kebangkitan" Islam politik, seperti merebaknya fenomena "radikalisme" Islam. ${ }^{110}$ Umumnya, istilah radikalisme dipakai baik oleh kalangan akademisi maupun media masa untuk merepresentasikan gerakangerakan Islam politik yang berkonotasi negatif seperti "ekstrem, militan dan intoleran" serta "anti Barat/Amerika." Hingga puncaknya ketika Amerika (waktu itu Presiden AS George W. Bush) mengumandangkan perang global melawan terorisme pasca peristiwa 11 September 2001, istilah radikalisme dan fundamentalisme kemudian dicampur adukkan dengan terorisme. ${ }^{11}$

Dalam laporan yang ditulis Mohammad Zulfan Tadjoeddin dari United Nation Support Facility for Indonesian Recovery (UNSFIR) tahun 2002, menunjukkan jumlah kekerasan sejak 1998 melesat naik. Laporan itu berisi, di tahun itu, 124 insiden terjadi dengan korban tewas 1.343 orang. Dua tahun sebelumnya (1996), teriadi 8 insiden dengan jumlah korban tewas 227 orang. Pada tahun 1997, terjadi 15 insiden dengan 131 korban tewas. Setahun pasca Suharto jatuh (1999), jumlah insiden masih terus menanjak, jumlahnya mencapai 300 insiden dengan 1.813 korban tewas. Pada tahun 2000, menjadi 408 insiden dengan 1.617 korban. Sedangkan pada tahun 2001 menjadi 233 insiden dengan korban terwas 1.065 orang.

110 "Dalam beberapa literatur istilah Islam politik, radikalisme atau neofundamentalisme atau revivalisme Islam memiliki tafsiran yang sulit untuk dibedakan satu sama lain. John L. Esposito (1997), misalnya menyamakan istilah Islam politik dengan "fundamentalisme Islam" (ditulis dalam tanda kutip) atau gerakan-gerakan Islam lainnya. sementara Oliver Roy (1994) cenderung menafsirkan Islam politik sebagai aktivitas kelompok-kelompok yang meyakini Islam sebagai agama dan sekaligus sebagai ideology politik "the activist religion". Sedikit berbeda dengan Esposito, Roy lebih spesifik lebih merujuk pada apa yang la sebut sebagai gerakan neofundamentalism yang antara lain menghendaki pemberlakuan syariat Islam." Lihat, Afadlal, dkk, Islam dan Rasikalisme di Indonesia (Jakarta: LIPI Press, 2005)

${ }^{111}$ Ibid. 
Baru-baru ini Wahid Foundation bekerja sama dengan Lembaga Survey Indonesia (LSI) melansir sebuah survei. Suvei Nasional yang melibatkan rensponden dari 34 provinsi di mana survey ini memunculkan sebuah data dan fakta yang mengejutkan bahkan mengkhawatirkan: Mayoritas muslim Indonesia (72\%) MENOLAK tindakan radikal. 7,7 \% yang BERSEDIA melakukan tindakan radikal bila ada kesempatan dan 0,4 yang PERNAH melakukan tindakan radikal. Karena ternyata sikap intoleran dari masyarakat Indonesia meningkat, artinya cukup banyak orang Indonesia yang tidak toleran terhadap perbedaan baik perbedaan agama, golongan, keyakinan dan yang menarik juga adalah ada kecenderungan semakin tinggi orang-orang yang tidak mau bertetangga dengan orang yang berbeda agama.

Indonesia, dengan kesatuan dan keragaman "unity in diversity" yang dimilikinya, maka untuk membendung isu radikalisme menurut $\mathrm{KH}$. Hasyim Muzadi sebagaimana dikutip oleh Syamsul Arifin dibutuhkan pendekatan secara menyeluruh, sistemik, semesta, dalam pengertian melibatkan berbagai institusi. Untuk mengatasi dampak gerakan kelompok Islam radikal, aparat keamanan tidak bisa bertindak sendirian, kata Hasyim Muzadi. Mengambil contoh terorisme, Muzadi memandang penting keterlibatan masyarakat sipil. Sebab tanpa keterlibatan masyarakat sipil akar terorisme tidak bisa dibasmi sampai ke akarnya. ${ }^{112}$

Keterlibatan masyarakat sipil sebagai sistem autopoisis (sistem yang bisa memperbaiki dirinya sendiri) telah dipraktikkan sebenarnya sebelum republik ini ada. Di Lombok Barat misalnya, sistem solidaritas antar warga secara komunal bahu-membahu saling tolong-menolong dalam segala hal. Pertemuan antar warga ini dahulunya dikenal dengan istilah Krame Banjar. Secara harfiah Krame Krame Banjar adalah perkumpulan antar warga yang beranggotakan orang-orang dari beberapa dusun.

${ }^{112}$ Syamsul Arifin, Membendung Arus Radikalisasi di Indonesia, Volume 8, Nomor 2, Maret 2014, ISLAMICA, 393, Lihat juga, Hasyim Muzadi, "Terorisme adalah Musuh Islam", dalam Muhammad Tahir-ul-Qadri, Fatwa tentang Terorisme dan Bunuh Diri (Jakarta: LPPI dan Minhaj-ul-Qur'an International), 16. 
Krame Banjar jika disepadankan dengan Publik Sphare di zaman modern ini.

Desa-desa di pulau Lombok, NTB memiliki corak kearifan lokal bagaimana bermusyawarah di balai gubuk, merencanakan, mengatur, melaksanakan, mengawasi dan menyelesaikan masalah-masalah gubuk. Tradisi dialog di kampung-kampung dengan dipimpin oleh tetua (tokoh-tokoh seperti kepala adat, tuan guru dan lain-lain) kiranya mampu meng-Counter radikalisme dan terosisme di tingkat desa maupun mendiskusikan penanganannya oleh pemerintah desa.

Sebab setiap dialog gubuk akan melahirkan tindakan-tindakan bersama. Dialog di Krame Banjar (setiap desa memilikinya) menjadi titik awal suatu kesepakatan komunikasi bersifat kekeluargaan. Awik-awik yang lahir dari kesepakatan karma desa berupa suatu ketentuan yang mengatur tata pergaulan hidup, membina solidaritas dalam masyarakat untuk mewujudkan kehidupan yang aman di masyarakat. Menurut Juhaepa dan Sarpin dalam Papernya mengatakan:

"Suku Sasak dengan tradisi dan bahasa Sasaknya merupakan suatu kelompok suku bangsa dari sekian banyak suku bangsa di Indonesia yang mempunyai keunikan dan tradisi dalam menjalani kehidupannya. Tradisi yang dibangun oleh Suku Sasak sebagai cermin dari sebuah peradaban masyarakat. Pola konsepsi mereka bangun melalui perjalanan yang cukup panjang melalui interaksi dengan suku-suku bangsa lain, di samping melalui perenungan dan pengamatan yang tajam terhadap fenomena alam, sehingga Suku Sasak memiliki banyak ragam adat dan budaya yang khas, diantaranya adalah budaya banjar. Budaya banjar pada komunitas Suku Sasak di daerah Nusa Tenggara Barat (NTB) menjadi sesuatu yang sangat penting, karena termasuk salah satu wadah sosial yang digunakan dalam berbagai upacara adat dan kegiatan kemasyarakat. Sehingga dapat dikatakan bahwa banjar sebagai salah satu karakteristik kebersamaan masyarakat Suku Sasak." ${ }^{113}$

113Juhaepa dan Sarpin, Fungsi Banjar Dalam Budaya Suku Sasak Terhadap Solidaritas Sosial Masyarakat Di Desa Watumelewe Kecamatan Tinanggea Kabupaten 
Lebih lanjut Juhaepa dan Sarpin dalam Paper tersebut menunjukkan bahwa terdapat dua bentuk banjar yang fungsional dalam budaya Suku Sasak, yaitu banjar merariq ${ }^{114}$ dan banjar mate. ${ }^{115}$

"Fungsi ekonomi dan sosial banjar diwujudkan melalui kewajiban anggota banjar memberikan bantuan materiil maupun non materiil kepada anggota banjar yang hendak melaksanakan hajatan dan terkena musibah. Perubahan yang bersifat positif adalah keanggotaan banjar ini tidak hanya dari kalangan komunitas Suku Sasak, tetapi juga dari komunitas lain. Perubahan yang bersifat negatif adalah nilai kerjasama dan kebersamaan yang mulai menurun akibat sudah kurangnya kepudulian beberapa anggota banjar kepada anggota banjar yang membutuhkan bantuan."

Krame Banjar sebagaimana dikenal oleh masyarakat Lombok Barat memiliki peran yang cukup signifikan, awik-awik ${ }^{116}$ adalah salah satu produk dari Krame Banjar ini. Awik-Awik sendiri berfungsi untuk membatasi warga banjar untuk bertindak menyalahi kesepakatankesepakatan banyak orang, awik-awik biasanya tidak tertulis karena ia lahir dari pertimbangan common sense.

Dalam Paper ini, peneliti tertarik meneliti tentang peran Krame Banjar dalam menangkal wacana radikalisme yang nanti membuahkan judul "Revitalisasi Peran KrameBanjar Dalam Menangkal Wacana Radikalisme (Studi Kasus Di Desa Labuan Tereng Kecamatan Lembar Lombok Barat)"

Pemerintah sudah harus mulai untuk memberdayakan peran Krame Banjar bukan saja secara formalitas belaka (MUSDUS dan MUSDES), namun juga menghidupkan solidaritas banjar tanpa dipengaruhi oleh anggaran desa. Sebagaimana yang kita ketahui bersama penanganan

Konawe Selatan, SOCIETAL: Volume 1, No. 1, (Jurnal Pemikiran dan Penelitian Sosiologi, April 2014).

${ }^{114}$ Bahu membahu ketika salah satu warga merayakan pernikahan

115 Bahu membahu ketika salah satu warga terkena musibah (meninggal dunia)

${ }^{116}$ aturan-aturan tak tertulis masyarakat dusun 
terhadap symptom-symptom (gejala radikalisme) begitu represif selama ini dan tentu tidak memberikan solusi, malah semakin banyak. Seharusnya, Krame Banjar harus dibadankan menjadi suatu komunitas pembelajaran dalam komunitas dusun/banjar secara regenerasi akan pentingnya dialog desa sebagai penangkal radikalisme di tengahtengah masyarakat.

\section{B. Isu Teoritis Krame Banjar}

Dalam Paper ini peneliti menggunakan teori wilayah publik (public sphere). Adapun teori ini bermula digagas oleh Jurgen Habermas seorang sosiolog sekaligus filsuf Jerman dari mazhab frankfurt. Diskursus wilayah publik yang akan dibahas ini, tidak hanya sebatas memiliki arti saja, dan suatu konsep serta pemikiran tidaklah lahir dalam ruang yang hampa akan tetapi memiliki sejarah yang cukup panjang sehingga tema wilayah publik ini menjadi umum kita dengar. ${ }^{117}$

Mengenai diskursus wilayah publik sebenarnya sudah beredar dan menjadi sangat penting untuk dibahas, dimana tema ini sudah menjadi pembahasan di dunia Eropa. akan tetapi apa sesungguhnya yang dimaksud dengan wilayah publik, meskipun wilayah publik ini memiliki beragam arti, akan tetapi paling tidak kita memiliki pandangan tentang wilayah publik. Dalam sejarah revolusi Perancis Roger Chartier pernah memberikan pandangannya mengenai wilayah publik, bagi dia wilayah publik adalah:

"The public sphere as a space for discussion and exchange removed from the sway of state power." ${ }^{\prime 18}$

Jadi dalam pembentukan opini publik itu sebenarnya harus dijauhkan dari otoritas agama dan negara ataupun isu-isu yang lainnya, agar tidak terjadi seperti sejarah eropa dulu, agama dan negara sebagai spirit kepada setiap individu untuk bertindak sesuai aturan dan

${ }^{117}$ Jurgen Habermas, The Structural Transformation of The Public Sphere, An Inquiry IntoA Category of Bourgeois Society, Teri. Yudi Susanto, (Yogyakarta; Kreasi Wacana, 2007), 21.

${ }^{118}$ Miriam Hoexter $d k k$, The Public Sphere In Muslim Societies, (State University of New York Press, 2002), 17. 
norma yang diyakini dan sepakati dalam wilayah publik. Adapun menurut Nilufer Gole:

"In the global era, the public sphere is not limited to a single national language community. Rather than the discursive and regulatory or normative aspects of the public sphere, the antagonistic and the experimental dimensions of the public sphere need stressing. The performative and visual repertoire of action staged in a given physical locality opens the way for new forms of public agency and brings the cultural-artistic realm to the fore. Just as Jürgen Habermas did in his works, we need to revisit the relations between the public sphere and democracy and question the autonomous and interdependent aspects of both." 119

\section{Rasionalitas Komunikatif}

Habermas dalam rasionalitas komunikatifnya melandaskan pada rasionalitas instrumental. Rasionalitas Instrumental menurutnya adalah rasionalitas yang diarahkan pada kerja untuk mengejar seefektif dan seefisien mungkin dengan ukuran-ukuran yang jelas, bersifat mendominasi dan hegemoni. Sedangkan rasionalitas komunikatif adalah rasionalitas yang ditujukan untuk mencapai kesepahaman bersama antar individu melalui bahasa atau sarana-sarana komunikatif yang lain. ${ }^{120}$

Untuk mencari kesaling pengertian dalam praktik komunikatif harus memenuhi beberapa syarat (Validitas Claims). Adapun syarat-syarat tersebut ialah Pertama, kejelasan apa yang akan disampaikan sehingga apa yang ingin dikemukakan dapat dimengerti (understandability). Kedua adalah mengungkapkan suatu kebenaran (truth), Ketiga, mengungkapkan diri apa adanya dengan kejujurana (Sincerity).

${ }^{119}$ Nilufer Gole, The Forbidden Modern "Civilization and Veiling" (USA: The University of Michigan Press, 1996), h. 3-84. lihat juga Nilufer Gole, Public Space Democracy, (An article from www.eurozine.com), 9.

${ }^{120}$ Ahyar Yusuf, Pemikiran Kritis Kontemporer "Dari Teori Kritis, Cultur Studies, Feminisme, Postkolonial Hingga Multikultural, ( Jakarta: Raja Grafindo, 2016), 24. 
Keempat menyatakan sesuatu sesuai dengan aturan/norma komunikasi (Rightnees).

Di samping empat syarat validitas di atas Habermas juga menekankan komunikasi yang rasional atau komunikasi yang ideal. Komunikasi yang ideal itu dapat terwujud menurutnya dengan syarat setiap partisipan harus diberikan ruang untuk ikut terlibat secara aktif dalam diskusi dengan bebas mengajukan berbagai keberatan (kritik) atas sudut pandang peserta lain. Dialog yang berjalan haruslah bebas dari tekanan, dominasi dan permainan kuasa. Anggota dialog dapat memahami perbedaan klaim-klaim teoritis dari validitas di atas. Adanya persetujuan atau keputusan bersama (konsensus) rasional terbuka terhadap perubahan dan pertimbangan lebih lanjut. ${ }^{121}$

Adapun syarat tercapainya komunikasi yang Rasional Atau Ideal yaitu: Pertama, setiap partisipan dapat berpartisipasi aktif dan bebas mengemukakan pendapat, mengajukan pandangan baik berupa saran dan ktitik. Kedua, dialog mengalir tanpa tekanan dan paksaan dari individu maupun kelompok lain. Ketiga, setiap partisipan memahami setiap kriteria dan kalim-klaim validitas. Keempat, adanya persetujuan berdasarkan kesepakatan (konsensus bersama) secara terbuka dan rasional terhadapa setiap anggota dialog.

Di Nusa Tenggara Barat (NTB) sendiri, wilayah publik menjadi wadah diskursus tentang segala hal yang menyangkut kepentingan warga gubuk. ${ }^{122}$ Mereka bermusyarah baik tentang pembangunan tempat ibadah (masjid, pura, wihara, gereja) maupun masalah-masalah sosial kemasyarakatan semisal pernikahan adat, masalah keamanan dan lain sebagainya. Dengan adanya public sphare (biasanya terjadi di balai desa dan tempat ibadah semisal masjid dan mushola) masyarakat mendidkusikan, mengorganisasikan dan menentukan apa yang akan menjadi tindakan kolektif warga gubuk.

Public sphare dalam Paper ini mirip seperti Krame Banjar Desa Labuan Tereng, di mana tradisi paguwuban yang diwarisi secara turun-

\footnotetext{
121 Ibid., 27.

${ }^{122}$ Dalam bahasa sasak adalah kampung
} 
temurun oleh masyarakat adat. Mendiskusikan, mendialogkan apa yang menjadi keperluan dan diputuskan bersama (awik-awik) sebagai sebuah konsensus yang akan dilakukan atau ditaati bersama.

\section{Peran Krame Banjar Dalam Menangkal Wacana Radikalisme}

Perkembangan media misalkan memberikan dampak yang luar biasa bagi efisiensi kehidupan manusia, baik produktifitas maupun mengembangan pengetahuan. Namun teknologi media juga membawa masalah ikutan semisal membeludaknya informasi yang terus-menerus menghampiri melalui satu device Samart Phone dengan jaringan internet. Media Sosial dalam internet SmartPhone memanjakan penggunanya, terdapat ribuan kontak yang dapat terjalin baik melalui pesan teks, gambar, panggilan maupun video call. Media medern akhirnya melahirkan generasi pecandu hoax.

Pada tahun 2013 kominfo.go.id meliris pengguna internet saat itu sebanyak 63 juta jiwa dan bertambah menjadi 132 juta. Sebanyak $95 \%$ pengguna internet di indonesia adalah pengguna media sosial. Umat Islam di Indonesia mencapai lebih dari 207 juta jiwa, dan merupakan pengguna media sosial aktif. $85 \%$ masyarakat indonesia memiliki ponsel dengan $43 \%$ di antaranya adalah Smartphone. Jumlah ponsel yang terjual jauh melebihi jumlah total populasi indonesia yang mencapai 300 juta unit. Artinya adalah satu orang dapat memiliki dua atau lebih ponsel di tangan. Belum lagi kita berbicara penggunaan mereka terhadap media sosial, pengguna internet tercatat sebanyak 100 juta jiwa dengan $79 \%$ adalah pengguna aktif facebook.

Telah terjadi pengikisan norma-norma karena, banyak orang memilih bersosialisasi melalui media sosial. Sebab dunia sosial media tidak hanya digunakan menjalin hubungan namun juga menjadi media informasi bagi banyak kalangan. Namun di tengah perkembangan media yang begitu pesat justru menjadi akar masalah dari problem berbangsa dan bernegara kahir-akhir ini. Ujaran kebencian ditebar ke mana-mana, hujatan, hasutan, faham radikalisme dengan akun-akun 
palsu, gerakan-gerakan Islam politik yang berkonotasi negatif seperti "ekstrem, militan dan intoleran" serta "anti Barat/Amerika" timbul tenggelam serta konsisten memprovokasi target mereka masing-masing.

Di Desa Labuan Tereng telah mengalami perubahan yang signifikan sejak pemekarannya dari desa Sekotong Timur membuat desa ini mandiri. Posisinya yang strategis, dekat dengan Pelabuhan Lembar yang mana ia merupakan gerbang nasional dari pulau Bali yang kemudian berdampak pada kesadaran warganya akan informasi. Dengan kesadaran bahwa arus informasi dan transportasi yang terus menerus tanpa henti para orang tua di Desa Labuan Tereng menghawatirkan pengaruh dari budaya-budaya barat, faham radikalisme menjangkitin para remaja mereka, oleh sebab itu Krame Banjar di desa itu tetap digalakkan.

Seperti yang dikatakan Arifrahman Hakim ketua karang taruna Desa Labuan Tereng:

"ada kekhawatiran dari para orang tua kami di sini terhadap pergaulan ramaja di Desa ini. Budaya Pop mempengaruhi cara mereka berinteraksi, hormat kepada orang tua sudah mulai terkikis. Namun kami di karang taruna ini menyadari itu dan selalu diajak dalam rapat gubuk bagaimana menanggapi isu-isu seperti itu. Ketika terjadi tindakan kriminal seperti maling masyarakat di sini mendiskusikan apa yang harus diperbuat semisal membuat dan menghidupkan post ronda, itu menjadi keputusan bersama." 123

Rapat gubuk atau Krame Banjar di Desa Labuan Tereng menjadi merevitalisasi wacana radikalisme yang berkembang baik lokal maupun nasional. Sifat kekeluargaan dalam Krame Banjar membuatnya efektif dalam menangkal wacana yang berkembang baik melalui berita-berita hoax di media sosial sebab sesepuh gubuk (para orang tua di desa) masih didengar dan dihormati oleh warga masyarakat Desa Labuan Tereng.

${ }^{123}$ Arifrahman Hakim (ketua Karang Taruna), Wawancara 10 Agustus 2017. 
"kami tidak pernah terpengaruh oleh isu-isu anti pancasila, anti NKRI, jihad dan lain sebagainya sebab dalam Krame Banjar kami isu-isu tersebut tidak diminati, kami memiliki orang tua, kiai, tuan guru, sesepuh yang kami dengar"124

Dalam Krame Banjar menurut H. Zurkarnaen setiap warga dapat berpartisipasi aktif dan bebas mengajukan pandangan dan kritik, berjalan tanpa paksaan, dominasi dan permainan kuasa, dan setiap warga memahami setiap kriteria dan klaim-klaim aturan serta adanya persetujuan/awik-awik adat istiadat-terbuka. Dalam hal ini ustadz Hamdani mengatakan:

"Dengan keberadaan Krame Banjar disetiap dusun ini dapat menangkal wacana-wacana radikalisme, apa lagi zaman sekarang media begitu terbuka, arus globalisasi sampai masuk ke desa-desa sehingga apa yang terjadi di belahan dunia mana pun dapat kita baca, tonton dan dengarkan. Akibat globalisasi ini tidak ada sekat antara kota dan pelosok desa.... keberadaan Krame Banjar minimal memberikan proteksi sistem sosial kemasyarakatan baik dalam berdialog dan memupuk tali silaturahmi antar warga sebagai satu kesatuan ukuwah Islamiyah" 125

\section{E. Revitalisasi Peran Krame Banjar}

Krame Banjar adalah kearifan lokal yang sejak lama dirawat turun temurun oleh masyarakat desa, ia berfungsi sebagai wadah untuk mendialogkkan kepentingan-kepentingan bersama terkait kemasyarakatan dengan mengutamakan transparansi dan saling pengertian yang berbasis kekelvargaan. Eksistensi Krame Banjar dalam dunia kontemporer ini mengalami tantangan yang luar biasa di mana anggota-anggota masyarakat semakin sibuk dengan urusan masingmasing, semakin individualistis. Sebagaimana pendapat Humaidi:

"masyarakat hari ini tidak seperti masyarakat zaman dahulu, kalau dulu cukup kita panggil untuk gotong royong lewat

${ }^{124}$ H. Zulkarnaen (tokoh masyarakat), Wawancara 29 Juli 2017.

125 Ustadz Hamdani (penghulu Desa), Wawancara, 20 Agustus 2017. 
pengeras suara masjid pasti banyak yang datang, kalau sekarang itu berubah. Ini disebabkan mungkin oleh kesibukan ataupun pergantian generasi baru...... Krame Banjar di sini berfungsi sebagai wadah ketika terjadi konflik aliran pada tahun 2006 lalu, setiap orang berhak berpendapat sedangkan pihak yang lain berkewajiban untuk mendengarkan. Kerame Banjar dimanfaatkan oleh Pemerintah sebagai wadah menyampaikan informasi terkait pembangunan desa baik fisik maupun sumberdaya manusia." 126

Krame Banjar menurut Humaidi adalah upaya kampung memberikan ruang demokratis, yang mana warga masyarakat dapat menyatakan opini, kepentingan dan kebutuhan mereka secara diskursif. Berkomunikasi mengenai kegelisahan-kegelisahan politis mereka, Krame Banjar biasanya diadakan dibalai banjar desa, gazebo, masjid, mushola maupun rumah warga. Menurutnya di setiap kampung memiliki Krame Banjar maka solidaritas antar warga akan tercipta sebagaimana yang berlaku di Desa Labuan Tereng ini. Krame Banjar tidak terlepas pada orang tua saja, namun melibatkan anak muda dan anak-anak sebagai generasi penerus tradisi di desa Labuan Terang. Merawat Krame Banjar merupakan suatu hal yang sangat vital di saat gempuran budaya-budaya luar di desa Labuan Tereng sebagaimana telah dijelaskan di awal Desa Labuan Tereng sangat dengan pelabuhan yang mana akses tranportasi dan komunikasi begitu terbuka.

Pemerintah harus memikirkan bagaimana Krame Banjar di pulau lombok secara khusus dan Indonesia secara umum di setiap kampung di hidupkan kembali, proses paguyuban, dialog antar warga, sehingga menjadi system early information menangkal arus wacana radikalisme.

\section{F. Awik-Awik Sebagai Konsensus}

Konsensus dalam Krame Banjar menjadi sangat penting, sebab keputusan-keputusan dalam dialog haruslah terdokumentasikan baik sebagai awik-awik (aturan tak tertulis) maupun peraturan dusun dan

${ }^{126}$ Humaidi (kepala desa), Wawancara, 16 Agustus 2017. 
desa. Awik-awik merupakan hukum adat yang disusun dan harus ditaati oleh setiap warga masyarakat dusun atau banjar. Pada zaman dahulu awik-awik memang hanya menjadi aturan tak tertulis namun pada zaman kontemporer ini awik-awik difasilitasi oleh pemerintah sehingga menjadi aturan dusun dan desa yang legal formal.

Dalam menciptakan aturan adat seperti awik-awik ini masyarakat dari anggota dialog harus diberikan kesempatan mengutarakan pendapatnya, meskipun tidak semua masyarakat vokal dalam berbicara di depan umum namun perwakilan atas kepentingan bersama harus diberikan ruang diskursus sehingga melahirkan kesaling pengertian antar sesama warga.

\section{G. Kesimpulan}

Adanya Krame Banjar di Desa Labuan Tereng menjadi merevitalisasi wacana radikalisme yang berkembang baik lokal maupun nasional. Sifat kekeluargaan dalam Krame Banjar membuatnya efektif dalam menagkal wacana yang berkembang baik melalui berita-berita hoax di media sosial sebab sesepuh gubuk (para orang tua di desa) masih didengar dan dihormati oleh warga masyarakat Desa Labuan Tereng.

Dalam merevitalisasi peran Krame Banjar tentu harus adat positif yang terbangun seperti awik-awik, karena awik-awik ini sebagai wilayah publik untuk menciptakan tindakan komunikatif dan media konsensus masyarakat dan harus diberikan kesempatan mengutarakan pendapatnya, meskipun tidak semua masyarakat vokal dalam berbicara di depan umum namun perwakilan atas kepentingan bersama harus diberikan ruang diskursus sehingga melahirkan kesaling pengertian antar sesama warga.

Memberikan ruang demokratis, yang mana warga masyarakat dapat menyatakan opini, kepentingan dan kebutuhan mereka secara diskursif. Di samping itu untuk menciptakan Krame Banjar tentu komunikasi sangat penting sebagai sarana dalam menyampaikan kegelisahankegelisahan politis masyarakat. Oleh karenanya di setiap kampung 
harus memiliki Krame Banjar sebagai arena menangkal isu-isu radikalisme, karena dengan adanya Krame Banjar kebersamaan dan solidaritas antar warga akan tercipta sebagaimana yang berlaku di Desa Labuan Tereng ini. 


\section{Daftar Pustaka}

-------, Islam dan Pluralism, Dalam Bassam Tibi, et al, Etika Politik Islam Civil Society, Pluralism, dan Konflik, (Jakarta: ICIP, 2005). -------, The Forbidden Modern Civilization and Veiling, (USA: The University of Michigan Press, 1996).

Afadlal, dkk, Islam dan Rasikalisme di Indonesia, (Jakarta: LIPI Press, 2005)

Arifin, Syamsul, "Membendung Arus Radikalisasi Di Indonesia", (Volume 8, Nomor 2, Maret 2014).

Arifrahman Hakim (Ketua Karang Taruna), Wawancara 10 agus Tus 2017.

Dale F. Eickelman and James Piscatori, Muslim Politics, (United States of America: Princeton University Press, 1996)

Dedi Putrawan, Agus, Runtuhnya Karisma Tuan Guru, (Mataram: Sanabil, 2017).

Eickelman, James, "Public Islam and Common Good," E† al, Public Islam and the Common Good. (Leiden; Boston, Brill, 2004).

Gole, Nilufer, "Public Space Democracy", (An article from www.eurozine.com).

Habermas, Jurgen, The Structural Transformation of the Public Sphere, An Inquiry IntoA Category of Bourgeois Society, Teri. Yudi Susanto, (Yogyakarta; Kreasi Wacana, 2007).

Hoexter, Miriam dkk, The Public Sphere in Muslim Societies, (State University of New York Press, 2002).

Juhaepa dan Sarpin, "Fungsi Banjar Dalam Budaya Suku Sasak Terhadap Solidaritas Sosial Masyarakat Di Desa Watumelewe Kecamatan Tinanggea Kabupaten Konawe Selatan", SOCIETAL: (Jurnal Pemikiran dan Paper Sosiologi; Volume 1, No. 1, April 2014).

Kari Telle, Vigilante Citizenship: Sovereign Practices and the Politics of Insult in Indonesia, (Bergen: Chr. Michelsen Institute CMI, 2013). 
Mufid, Ahmad Syafi'i, "Peta Gerakan Radikalisme Di Indonesia", Dalam Workshop Membangun Kesadaran dan Strategi Menghadapi Radikalisasi Agama, (Palu, 22 Mei 2012).

Muzadi, Hasyim, "Terorisme adalah Musuh Islam", dalam Muhammad Tahir-ul-Qadri, Fatwa tentang Terorisme dan Bunuh Diri (Jakarta: LPPI dan Minhaj-ul-Qur'an International).

Notosusanto, Nugroho, Sejarah Nasional Indonesia: "Zaman Pertumbuhan dan Perkembangan Kerajaan-Kerajaan Islam di Indonesia" Cet. 2, (Jakarta: Balai Pustaka, 2008),

W. Arnold, Thomas, Sejarah Dakwah Islam, Teri. Nawawi Rambe, (Jakarta: Penerbit Wijaya, 1981).

Yusuf, Ahyar, Pemikiran Kritis Kontemporer "dari teori kritis, cultur studies, feminisme, postkolonial hingga multikultural, ( Jakarta: Raja Grafindo, 2016). 